\title{
FAMILY'S SUPPORT, PARTNERSHIP AND NUTRITION STATUS OF CHILDREN UNDER THE AGE OF FIVE IN THE SPECIAL REGION OF YOGYAKARTA
}

\author{
Fatimah Sari ${ }^{1 *}$, Bhisma Murti ${ }^{2}$, Endang Sutisna $\mathrm{S}^{2}$ and Kusnandar ${ }^{2}$ \\ ${ }^{1}$ College of Health Science Guna Bangsa Yogyakarta, Indonesia \\ ${ }^{2}$ Post Graduate Programme, Sebelas Maret University, Surakarta, Indonesia
}

Corresponding author: Fatimah Sari

Email: fatimahsari.gunabangsa@gmail.com

\begin{abstract}
Nutritional problems are issues that affect individuals or communities as a result of poor diets that lack essential nutrients. At the age of fifteen months, nearly one-third of children in developing countries are malnourished, with the majority of them being the proportion of children with height for age below standard derivations (stunting), the proportion of children with weight for height below standard derivations (wasting), and underweight. This was a quantitative study with a cross-sectional approach. This research was conducted in eight local-public health centers in the Special Region of Yogyakarta in December 2018 until February 2019. The population of this research was children under the age of seven with the total sample of 383 children. This research was analyzed using univariate and bivariate analysis. Univariate analysis was used to determine the frequency, mean value, variation, and percentage distributions, which are expressed in $n$ and percent. Bivariate analysis was used to determine the relationship between the independent and dependent variables. The statistical test used was a different proportion test with Chi-Square, Cl (95\%), and level of significance. The bivariate analysis result showed that the lack-family-support children under the age of five had the higher risk of experiencing underweight 0.04, stunting 0.28 and wasting 0.30 . In addition, the children under the age of five who had lack of family-health worker cadre partnership had the higher risk of being underweight 0.36 , stunting 0.43 , and wasting 0.42 . In conclusion, the nutritional status of the children under the age of five (underweight, stunting, and wasting) was indirectly affected by the variable of family support and familyhealth worker cadre partnership.
\end{abstract}

Keywords: Family support, Partnership, Nutritional status

\section{INTRODUCTION}

Underweight is directly caused by inadequate food intake/poor diet, specifically lacks of essential nutrients that the body needs ${ }^{1}$. The community nutrition improvement and welfare carries out through continuous care approach. This approach starts according to the life cycle from pregnancy, childbirth, postpartum mothers, babies, toddlers, teens, adults and the elderly. The intervention priority in the first 1000 days of life is during pregnancy until the child is in the age of twenty three months ${ }^{2}$.

In comparison to other middle-income countries, Indonesia has a high prevalence of stunting. In 2019, the prevalence of stunting in Indonesia was 27.7 percent, which means that 28 out of every 100 children under the age of five are stunting. ${ }^{2}$ Nutrition for infancy and childhood at an early age must meet physiological requirements and support healthy growth and normal development ${ }^{3}$. Indonesian food consumption contains a variety of nutrients such as calories, protein, carbohydrates and fats. Two essential nutrients for children under the age of five are calories and protein. Calories are needed by the body especially as a source of energy. Inadequate calorie intake has a negative impact on health. A lack of calories weakens the body and weakens the immune system. A high protein diet can have negative effects on the body, particularly kidney damage. Excess calories are also bad for your health because they can lead to weight gain over time. Protein is an important nutrient for the body, particularly for the development and repair of body tissues ${ }^{4}$.

Community nutrition development aims at increasing the scope and the quality of family nutrition services to improve the nutritional status of pregnant women, nursing mothers, infants, and children under the age of five. Those activities include promotion and prevention. Both promotion and prevention are carried out by the community and health-officer at the community level. The activities are growth monitoring, health education, counseling about the feeding of infant and children under the age of five, administering high doses of vitamin capsules every 6 months, giving blood tablets to pregnant women, promoting iodized salt, tracking and following-up on malnutrition cases. Preventive activities include providing supplementaryrecovery food for undernourished and underweight children. Supplementary food is provided in the form of local food as prescribed. Curative activities such as malnutrition management for both inpatient and outpatient use stated protocols ${ }^{2}$. 
One effort to reduce the number of malnourished children under the age of five is by giving supplementary food to support breast milk for the children under the age of two from poor families as the Minimum Service Standard of the Nutrition Program with a target of $100 \%$. Nutrition recovery houses in the special region of Yogyakarta were established in 2010. It is established because of nutrition problems where malnourishedchildren under the age of five do not have special access to consult freely to pediatricians in the local public health service center because the service is still centralized in the hospital, there is no comprehensive rehabilitation center for malnourished children under the age of five and to get consulting services to pediatricians for malnourished children under the age of five ${ }^{5}$.

Children under the age of five with improved nutritional status are the result of comorbidities and poor early childhood education. These issues necessitate the involvement of various sectors in breeding education, childhood education for children under the age of five, and comorbidity management. The study needs to be done since there were malnourished children under the age of five with the total of 589 and children under the age of five growths under the standard with the total of $148^{5}$.

\section{METHODS}

This was a quantitative research with a crosssectional study approach. The cross-sectional study aims to describe the disease and exposure in populations at a particular time. The data of cross-sectional studies are in the form of prevalence data. Prevalence is the proportion of cases in a population at one time 6 . The purpose of this study was to analyze the direct influence of family support on the nutritional status of children under the age of five (underweight, wasting and stunting) and analyze the direct effect of family-health worker cadre partnershiptoward the nutrition status of children under the age of five (underweight, wasting and stunting). The study was conducted at the local public health centers in the special region of Yogyakarta, Indonesia in December 2018 until February 2019. The target population in this study was children under the age of five (12 - 60 months) with the total of 8.902. The source population is mothers who have children under the age of five.

The sampling was collected by using cluster sampling techniques to determine the total population of children under the age of five in eight local public health centers in the special region of Yogyakarta. The population wasdetermined based on the high nutritional status data in eight local public health centers in the special region of Yogyakarta in $2016^{5}$. The sample of this study was 383 children under the age of five with the total of 383 children.In this study, the independent variables were family support and family-health worker cadre partnership. The dependent variable was nutrition status (underweight, wasting and stunting). The hypothesis of this study was that there was a direct influence of family support and family-health worker-cadre partnership on the children nutrition status under the age of five (underweight, wasting and stunting).

\section{Operational Definition}

1. Family support is informational, instrumental, and emotional support provided by the husband/family.

2. Partnership (partnership of cadres-healthfamily officers) is a bond of cooperation and mutual need between partnerships of cadreshealth-family officers in nutritional assistance for children under the age of five, including access to health information, health assistance and partnership performance.

3. Nutritional status is the physical condition of children under the age of five, as measured by the Z-score anthropometric index with indicators $(W / A),(H / A)$, and $(W / H)$.

\section{Research Procedure}

The data collection techniques consisted of primary and secondary data. The primary data were obtained directly from the first data source at the research location or research object, namely from the child nutrition status under the age of five by measuring according to the age, weight based on height, and height based on age. The research instrument used for data collection in this study was a questionnaire. The questionnaire was given to the mothers who had a child under the age of five including family support and family-health worker-cadre partnerships. The secondary data were data obtained from the second source, namely from the Maternal and Child handbook $(\mathrm{MCH}$, in Indonesian: Buku Kesehatan Ibu dan Anak (KIA)), Integrated Service Post note, local public health service center and city health center notes from the special region of Yogyakarta.

Before being distributed to respondents, this research instrument was tested for validity and reliability. The results of the validity test for the statement of the family support variable showed that out of 12 statement items were declared valid. The results of the validity test on the statement of family-health worker-cadre partnerships variable showed that out of 8 items the statement was declared valid. Based on the reliability test of the research instrument, it was found that all the variables were considered reliable. In this study, researchers conducted anethical clearance test at the University of Jenderal Ahmad Yani Yogyakarta. The researcher asked for a research permit at the relevant agency, namely the Head of Yogyakarta City National Unity and Politics with a copy to the Head of the Yogyakarta City Investment and Licensing Office, the Head of the Yogyakarta City 
Health Office and the Head of the Yogyakarta Local Public Health Service Center in the Yogyakarta Municipality, then the preparation of questionnaire and informed consent forms.

Researchers assigned the assistants in the study (enumerators) consisting of four enumerators whose role was to provide an explanation to the subject of the study when filling out the questionnaire. Researchers shared the same perception as four enumerators and prepared technical implementation in the field, preparing research targets beginning with determining the research area, that is 8 local public health service centers in the special region of Yogyakarta as research locations based on geographical areas and from high nutrition status figures in eight local public health service centers in the Yogyakarta Municipality in 2016. The researchers coordinated with the Head of Administration and Nutrition Officer at 8 local public health service centers in the special region of Yogyakarta to discuss the technical implementation of the study by bringing a copy of the research permit from the Yogyakarta City Investment and Licensing Office. Mothers with children under the age of five were asked to fill out informed consent, and the enumerator explained everything so that the respondent understood first before filling out all the statements contained in the questionnaire. Researchers measured weight and height to determine the nutritional status of children under the age of five.

Data entry was used to process the data, which was then coded according to categories so that it could be analyzed. The research findings were then interpreted by comparing theories to the findings. STATA 13, a computer program, was used to collect the data. Univariate analysis was used to determine the distribution of frequencies,

Table 1: Research Sample Characteristics mean values, variations, and percentages for a single variable. Univariate analysis in this study were: sex of children under the age of five, mother employment status, family income, mother's education, family support, family-health worker-cadre partnerships and nutrition status of children under the age of five were described in $\mathrm{n}$ and $\%$. The family-health worker-cadre partnerships were a relationship partnership and mutual need between the family-health workercadre partnerships in the nutrition assistance of children under the age of five. Family support was information support, emotional/self-esteem support, and instrumental support provided by a husband/family. The nutrition status of children under the age of five was defined as their body condition as measured by the anthropometric index Z-score with indicators (weight/age), (height/age), and (weight/height).

Bivariate analysis between variables in the study was conducted to determine the relationship between the independent variable and the dependent variable. The independent variables in this study were family support and family-health worker-cadre partnerships. The dependent variable is Nutrition Status. The statistical test used was a different proportion test using Chissquare, with $\mathrm{Cl}$ (95\%) and significance level.

\section{RESULTS}

Table 1 showed the sex ratio of children under the age of five, with 197 male respondents $(51.40 \%)$ and 186 female respondents ( $41.60 \%)$. According to the data on mother's employment status, there were 128 working mothers (33.40\%) and 255 housewives $(66.60 \%)$.

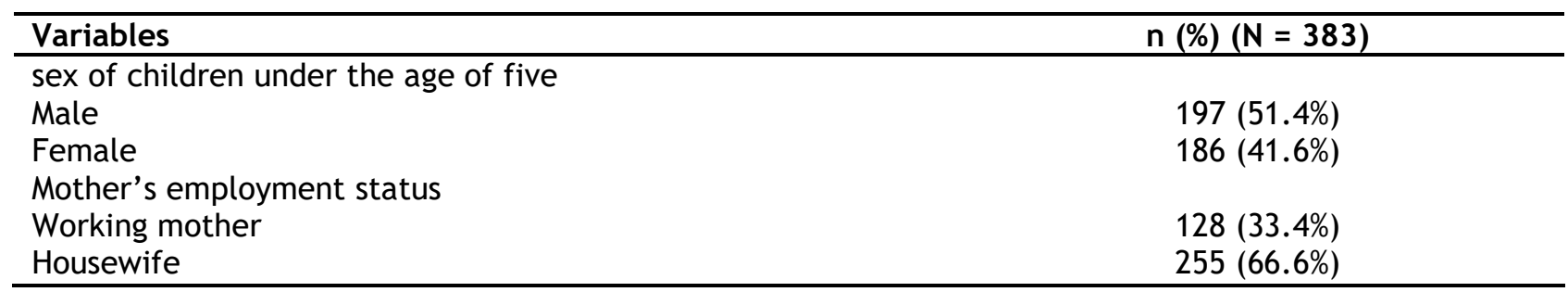

Based on the data in table 2 , the majority of families had a high income $(\geq 1.700 .000)$ with a total of 197 people $(51.44 \%)$ and a low income (< $1.700 .000)$ with a total of 186 people (48.56\%). With a total of 267 people $(69.71 \%)$, the majority of mothers had low education (< Senior High School) and 116 people had high education ( $\geq$ Senior High School). According to nutritional weight based on age, the majority of children under the age of five had a good nutrition status with a total of 254 people $(66.32 \%)$ and were underweight with a total of 129 people (33.68\%). The nutrition status of children under the age of five was then classified as normal with a total of 250 people $(65.27 \%)$ and stunting with a total of 133 people. Additionally, the nutrition status of children under the age of five according to weight based on height was a normal status with the total of 332 people $(86.68 \%)$ and a wasting status with the total of 51 people (13.32\%). 
Most of the mothers with children under the age of five had a high support from their family with the total of 214 people $(55.87 \%)$. The analysis result of family's supports had 1-60 score. Twelve items of questionnaires to know family's support were to be rated in five scales: never (1), rarely (2), sometimes (3), very often (4), and always (5). Based on twelve items, the item number eight had the lowest score, namely "Instrumental support with the statement of whether or not a husband/family gives a loan when a mother needs a loan to buy staple food'. It showed that instrumental supports for a mother were still low.

In relation to family-health worker-cadre partnerships, most of the mothers with children under the age of five had a low partnership with the total of 212 people $(55.35 \%)$ and a strong partnership with the total of 171 people $(44.65 \%)$. The result of family-health worker-cadre partnership shad 1-40 score. Eight items of familyhealth worker-cadre partnerships were to be rated in five scales: never (1), rarely (2), sometimes (3), very often (4), and always (5). Based on eight items, the item number four had the lowest score, namely "health worker-cadres give health assistances on child feeding training to children under the age of five". It showed that health assistances from health worker-cadres to the family on child feeding training to children under the age of five were still low.

Table 3 showed the bivariate analysis result of family's support with the nutrition status of underweight children under the age of five. Children under the age of five with low family's support had a risk of underweight of 0.40 higher than children under the age of five with strong family's support $(\mathrm{OR}=0.40, \mathrm{Cl}(95 \%)=0.26$ to $0.62, p<0.001)$. The result of Chi-square test toward the independent variable on family's support with the dependent variable was the nutrition status of underweight children under the age of five causing a significant number. There was an effect of family's support toward the nutrition status of underweight children under the age of five with $p<0.001$.

The bivariate analysis result on family-health worker-cadre partnerships with the nutrition status of underweight children with the age of five was a mother who had low partnership had the risk of underweight 0.36 higher than a mother who had strong partnership $(\mathrm{OR}=0.36$, $\mathrm{Cl}(95 \%)=0.22$ to $0.56, p<0.001)$. The Chi-square test result toward the independent variable on family-health worker-cadre partnerships with the dependent variable was the nutrition status of underweight children under the age of five causing a significant number. There was an effect of family-health worker-cadre partnerships toward the nutrition status of underweight children under the age of five with $\mathrm{p}<0.001$.
Table 4 showed the bivariate analysis result of family's support on the nutrition status of stunting children under the age of five. Children under the age of five with low family's support had a risk of stunting 0.28 higher than children with strong family's support $(\mathrm{OR}=0.28, \mathrm{Cl}(95 \%)$ $=0.18$ to $0.44, \mathrm{p}<0.001)$. The Chi-square test result toward the independent variable of family's support with the dependent variable was the nutrition status of stunting children under the age of five causing a significant number. There was an effect of family's support toward the nutrition status of stunting children under the age of five with $p<0.001$.

The bivariate analysis result of family-health worker-cadre partnerships with the nutrition status of stunting children under the age of five. Children under the age of five with low familyhealth worker-cadre partnerships had a risk of stunting 0.43 higher than children with strong partnership $(\mathrm{OR}=0.43, \mathrm{Cl}(95 \%)=0.27$ to 0.67 , $\mathrm{p}<0.001)$. The Chi-square test result toward the independent variable of family-health workercadre partnerships with the dependent variable was the nutrition status of stunting children under the age of five causing a significant number. There was an effect of family-health worker-cadre partnerships toward the nutrition status of stunting children under the age of five with $p<0.001$.

Table 5 showed the bivariate analysis result of family's support on the nutrition status of wasting children under the age of five. Children under the age of five with low family's support had a risk of wasting 0.30 higher than children with strong family's support $(\mathrm{OR}=0.30, \mathrm{Cl}(95 \%)$ $=0.16$ to $0.58, p<0.001) .0 .30$ The Chi-square test result toward the independent variable of family's support with the dependent variable was the nutrition status of wasting children under the age of five causing a significant number. There was an effect of family's support toward the nutrition status of wasting children under the age of five with $\mathrm{p}<0.001$.

The bivariate analysis result of family-health worker-cadre partnerships with the nutrition status of stunting children under the age of five. Children under the age of five with low familyhealth worker-cadre partnerships had a risk of wasting 0.42 higher than children with strong partnership $(\mathrm{OR}=0.42, \mathrm{Cl}(95 \%)=0.21$ to 0.80 , $p=0.009$ ). The Chi-square test result toward the independent variable of family-health workercadre partnerships with the dependent variable was the nutrition status of wasting children under the age of five causing a significant number. There was an effect of family-health worker-cadre partnerships toward the nutrition status of wasting children under the age of five with $\mathrm{p}=0.009$. 
Table 2: General Unvaried Analysis of Research Data

\begin{tabular}{|c|c|}
\hline Variables & $n(\%)(N=383)$ \\
\hline \multicolumn{2}{|l|}{ Family Income } \\
\hline Low Income $<1,700.000$ & $186(48.56 \%)$ \\
\hline High Income $\geq 1,700.000$ & 197 (51.44\%) \\
\hline \multicolumn{2}{|l|}{ Mother's Education } \\
\hline $\begin{array}{l}\text { Low Education (Primary School, Junior High } \\
\text { School) }\end{array}$ & $267(69.71 \%)$ \\
\hline $\begin{array}{l}\text { High Education (Senior/Vocational High } \\
\text { School) }\end{array}$ & $221(30.29 \%)$ \\
\hline \multicolumn{2}{|l|}{ Family Support } \\
\hline Low Family Support & $169(44.13 \%)$ \\
\hline High Family Support & $214(55.87 \%)$ \\
\hline \multicolumn{2}{|l|}{ Family-health worker-cadre partnerships } \\
\hline Low Partnership & $212(55.35 \%)$ \\
\hline High Partnership & $171(44.65 \%)$ \\
\hline \multicolumn{2}{|l|}{ Weight based on Age } \\
\hline Z-Score < -2SD(Underweight) & $129(33.68 \%)$ \\
\hline Z-Score -2 SDuntil 2SD(Good Nutrition) & $254(66.32 \%)$ \\
\hline \multicolumn{2}{|l|}{ Height based on Age } \\
\hline Z-Score $<-2$ SD (Stunting) & $133(34.73 \%)$ \\
\hline Z-Score -2 SD until 2 SD (Normal) & $250(65.27 \%)$ \\
\hline \multicolumn{2}{|l|}{ Weight based on Height } \\
\hline Z-Score < -2 SD (Wasting) & $51(13.32 \%)$ \\
\hline Z-Score -2 SD until 2 SD (Normal) & $332(86.68 \%)$ \\
\hline
\end{tabular}

Table 3: Chis-square Test on the Effect of Independent Variable toward the Nutrition Status of Underweight Children under the age of five

\begin{tabular}{|c|c|c|c|c|}
\hline \multirow[t]{2}{*}{ Independent Variables } & $\begin{array}{l}\text { Underweight } \\
\text { (Weight/Age) }\end{array}$ & $\begin{array}{l}\text { Good Nutrition } \\
\text { (Weight/Age) }\end{array}$ & \multirow[t]{2}{*}{ OR } & \multirow[t]{2}{*}{$\mathrm{p}^{*}$} \\
\hline & n (\%) & n (\%) & & \\
\hline \multicolumn{5}{|l|}{ Family's Support } \\
\hline Low & $76(44.97)$ & $93(55.03)$ & 0.40 & $<0.001$ \\
\hline High & $53(24.77)$ & $161(75.23)$ & & \\
\hline \multicolumn{5}{|l|}{$\begin{array}{l}\text { Family-Health Worker- } \\
\text { Cadre Partnership } \\
\text { Low }\end{array}$} \\
\hline High & $\begin{array}{l}92(43.40) \\
79(37.09) \\
\end{array}$ & $\begin{array}{l}120(56.60) \\
134(62.91)\end{array}$ & 0.36 & $<0.001$ \\
\hline
\end{tabular}

Table4: Chis-square on the Effect of Independent Variable toward the Nutrition Status of Stunting Children under the Age of Five

\begin{tabular}{lcccc}
\hline $\begin{array}{l}\text { Independent } \\
\text { Variable }\end{array}$ & $\begin{array}{c}\text { Stunting } \\
\text { (Height/Age) }\end{array}$ & $\begin{array}{l}\text { Normal } \\
\text { (Height/Age) }\end{array}$ & OR & p* \\
\cline { 2 - 3 } & $\mathbf{n}(\%)$ & $\mathbf{n ~ ( \% ) ~}$ &
\end{tabular}

Family's Support

Low

High

$85(50.30) \quad 84(49.70)$

$48(22.43) \quad 166(75.57)$

$0.28<0.001$

Family-Health

Worker-Cadre

Partnership

Low

$91(42.93) \quad 121(57.07)$

High

$42(24.56) \quad 129(75.44)$

$0.43<0.001$ 
Table 5: Chi-square Test on the Effect Independent Variable toward the Nutrition Status of Wasting Children under the Age of Five

\begin{tabular}{|c|c|c|c|c|}
\hline $\begin{array}{l}\text { Independent } \\
\text { Variable }\end{array}$ & $\begin{array}{c}\begin{array}{c}\text { Wasting } \\
\text { (Weight/Height) }\end{array} \\
\mathrm{n} \mathrm{( \% )}\end{array}$ & $\begin{array}{l}\begin{array}{l}\text { Normal } \\
\text { (Weight/Height) }\end{array} \\
\mathrm{n} \mathrm{( \% )}\end{array}$ & OR & $\mathrm{P}^{*}$ \\
\hline
\end{tabular}

\section{Family's Support \\ Low}

High

Family Health

Worker Cadre

Partnership

Low $\quad 37(17.46)$

High
$35(20.71)$

$16(7.48)$

$14(8.18)$
$134(79.29)$

$198(95.52)$
$0.30<0.001$

\section{DISCUSSION}

The results of the study with the variable family income shows the high income of $51.44 \%$, the City Minimum Wage Income in the special region of Yogyakarta with the total of 1.700 .000 rupiahs. Increased family income in the household will result in better food quality for family members. Low income reduces the amount of food consumed by families and increases the risk of contracting infectious diseases, resulting in poor nutrition for children under the age of five. When income is low, the food consumed does not take nutrition into account, but the material value is taken into account ${ }^{7}$. The results of this study indicate that the mother's high education (JHS/VHS) level is $30.29 \%$. Mother's education has an important role to educate children in the family. Education is obtained through formal education, but it also possible for a mother to get an informal education. Higher education obtained by a mother makes a child shape his character and personality for the better. The higher a mothers level of knowledge, the higher her ability to capture information that can increase knowledge, and the easier it is to implement knowledge and attitudes toward nutritional problems in children under the age of five. According to the findings of Setyaningsih and Agustini's study, the majority of mothers are quite knowledgeable about the nutritional needs of children under the age of five. ${ }^{8}$

The results of the bivariate analysis of family support for the nutrition status of children under the age of five show that there is a direct effect of family support on the nutrition status of children under the age of five (underweight, stunting and wasting). Social support networks include a combination of actions primarily aimed at maintaining the physical and psychological health of individuals. The types of family support are informational support, assessment support, support, instrumental support and emotional support ${ }^{9}$. The results of the study Breastfeeding mothers exclusively receive good family support with $\mathrm{p}=0.001$, OR $(95 \% \mathrm{Cl}) 2.86(1.25-6.53)$. Family support and husband's education are the only factors influencing exclusive breastfeeding for working mothers ${ }^{10}$. Mothers who have strong family support are expected to have good and normal nutrition status of children under the age of five (underweight, stunting and wasting). Family support is one form of social support, where the existence of family support will create a successful level of good nutrition status and nutrition health status of children under the age of five to be good and normal. Strong family support can be realized if you obtain support from a husband and family who can be trusted, so that the mother knows she is paying attention, wants to hear all of her complaints, and sympathizes and empathizes with the problems she is facing. ${ }^{11}$

The results of the bivariate analysis of familyhealth cadre partnership on the nutrition status of children under the age of five shows that there is a direct effect of family-health cadre partnership with the nutrition status of children under the age of five (underweight, stunting and wasting). Human relations are very meaningful in social life. Human relations form a social group and close collaboration between individuals and families. The collaboration existing between cadres and health workers with the family, in this case the mother, will have a positive impact on the cadreshealth workers-family partnership.

Partnerships facilitate knowledge transfer. Knowledge transfer is built on a holistic understanding and is developed through trust, commitment, interdependence, togetherness and balanced strength ${ }^{12}$. Many cases of underweights indicate that nutrition intake at the family level is inadequate, therefore empowerment efforts are needed through family assistance.

Nutrition-aware family assistance is a process that encourages, motivates, guides, and facilitates cadres to help families limit nutrition problems ${ }^{13}$.Cadres act as actors in a health-care system. Cadre works at a public health center in the area. Cadre works at a public health center in the area. Cadres provide services such as measuring toddlers' height and weight, filling health cards (known as KMS cards in Indonesia), 
counseling and disseminating health information, and mobilizing mothers with toddlers to attend and participate in local public health center activities. A family health worker cadre partnership is critical in the activities of a local public health center. Cadres must be nurtured and developed through the guidance of health workers, in this case the local public health center as a $\operatorname{coach}^{14}$.

\section{CONCLUSION}

Chi-square test results on the independent variable of family support with the dependent variable namely the nutrition status of children under the age of five (underweight, stunting and wasting) produce statistically significant results. There is a direct effect of family support on the nutrition status of children under the age of five (underweight, stunting and wasting) $\mathrm{p}<0.001$. The results of the Chi-square test on the independent variable namely the family health worker cadre partnership with the dependent variable nutrition status (underweight and stunting) produce statistically significant results, the result is that there is a direct effect of the family health cadre partnership on the nutrition status of children in under the age of five (underweight and stunting) $p<0.001$ and there is a direct effect of the family-health cadre partnership on the nutrition status of children under the age of five (wasting) $p=0.009$. Family support (informational, emotional, and instrumental support) from the husband and closest family members is required to reduce the risk of children under the age of five developing nutritional status (underweight, stunting, and wasting). There is a need to update cadres' knowledge and skills to accompany children under the age of five through guidance and training from health workers about the nutritional status of children under the age of five, so that when integrated service post activities are carried out, they do not rely on health workers in the community health center working area. It is necessary to improve the knowledge and skills of health workers and integrated service post cadres in assisting children under the age of five by providing guidance and training on monitoring children's nutritional status.

\section{Conflict of interest}

The authors declare no potential conflict of interest.

\section{REFERENCES}

1. Unicef. 1998. Malnutrition :Causes, Consequences and Solutions. The State Of The World's Children.

2. The Indonesian Ministry of Health. 2014. Indonesian Nutrition Barometer. Jakarta: Directorate General of Nutrition and
Maternal and Child Health: Directorate of Nutrition Development

3. Koletzko B, Swajewska H, Ashwell M, Shamir R, Aggett P, Baerlocher K, Noakes P, Braegger C, Calder P, Campoy F, Cristina C, Virginie D, Tamas D, Magnus D, Christophe F, Mary VG, Johannes B, Michaelsen KF, Mihatsch W, Guarino A, Koletzko S, Rigo J, Turck D and Taminiau J. 2012. Documentation of Functional and Clinical Effects of Infant Nutrition. Journal Pubmed. $60 \quad$ (4), 22-32. https://doi.org/10.1159/000337681.

4. Central Statistics Agency. 2015. Indonesian Population Profile. Accessed March 30, 2017.

5. Yogyakarta City Health Service. 2016. Yogyakarta City Health Profile Dinas Kesehatan Kota Yogyakarta. 2016.

6. Murti B. 2013. Sample Design and Size for Quantitative and Qualitative Research in the Health Sector. Yogyakarta. Gadjah Mada University Press. Murti B. 2013.

7. Kusumaningrum RN. 2003. Effects of Mother's Education Level, Mother's Economic Activity, and Family Income on Toddler Nutrition Status in Simo District, Boyolali District. Thesi Faculty of Economics. Sebelas Maret University. Surakarta (Published).

8. Putra PH, Taufiq RA, and Juliani A. 2013. Study of Relationship between Education Level and Family Income Against Attitudes in Household Waste Management (Case Study in Condongcatur Village, Depok Sleman, Yogyakarta). National Journal of Environmental Science and Technology. 5 (2), 91-101.https: //doi.org/10.2.https://doi.org/10.20885/j stl.vol5.iss2.art3

9. Sarafino EP. 2006. Health Psychology: Biopsychosocial Interactions. Fifth Edition. USA: John Wiley \& Sons.

10. Dewi R, Bunga A P, Hamam H, Anafrin $Y$, Dewi A and Eka N. 2017. Family Support and Exclusive Breastfeeding Among Yogyakarta Mothers in Employment. Asia Pacific Journal of Clinical Nutrition. 26 (1), S31S35.https://doi.org/10.6133/apjen.062017 .s8.

11. Friedman MM. 2010. Textbook of Family Nursing: Research, Theory and Practice. Jakarta: EGC

12. He Q, Gallear D and Ghobadian A. 2011. Knowledge Transfer: The Facilitating 
Attributes in Supply-Chain Partnerships. International Journal Information Systems Management. 28

https://doi.org/10.1080/10580530.2011.5 36114.

13. RI Ministry of Health. 2007. Guidelines for Family Assistance Towards Kadarzi: Jakarta. Directorate General of Community Health Development: Directorate of Community Nutrition Development Departemen Kesehatan RI. 2007.
14. Nilasari B and Farich A. 2012. Relationship of Family Support and the Role of Cadres with the Participation of Elderly Participating in the Posyandu for the Elderly at Mawar Posyandu in Tri Rahayu Village, Katon District, Pesawaran Regency. World Journal of Public Health.1 (3), 127133.

https://doi.org/10.33024/jdk.v1i3.330. 